\title{
Differences in habitat use between the native Eurasian beaver and the invasive North American beaver in Finland
}

\author{
Riikka Alakoski (i) Kaarina Kauhala $\cdot$ Vesa Selonen
}

Received: 9 July 2018/ Accepted: 14 January 2019/Published online: 8 February 2019

(C) The Author(s) 2019

\begin{abstract}
Habitat requirements largely determine the distribution and abundance of a species. An invasive species can therefore threaten the survival of a native species, if the two species are similar in niche use. In Finland, the distribution of the invasive North American beaver (Castor canadensis) is approaching the range of the native Eurasian beaver (Castor fiber) possibly creating a threat for the latter. We compared the habitat use of the native and invasive beaver species in Finland in the main distribution of the species and within a smaller area where the species live in sympatry. We compared the used habitats (volume of birch and other deciduous trees and distance to agricultural and urban areas) at beaver lodges and at random locations in the available riparian habitat with (conditional) logistic regression models. Results indicated that the native beaver lodges were located closer to agriculture than those of the invasive beaver. The volume of birch was also slightly greater near the lodges of the native beaver than those of the invasive beaver. However, habitat use of both of the species seemed quite flexible, because the habitat near lodges did not differ much from the available
\end{abstract}

R. Alakoski $(\bowtie) \cdot$ V. Selonen

Department of Biology, University of Turku,

20014 Turku, Finland

e-mail: riankra@utu.fi

K. Kauhala

Natural Resources Institute Finland Luke, Itäinen

Pitkäkatu 4 A, 20520 Turku, Finland habitat. We conclude that the probability that the North American beaver will invade the distribution area of the Eurasian beaver in Finland depends, at least partly, on the ability of the former to live in proximity to agricultural areas. However, methods other than those related to managing habitat quality may be the best approach to controlling the invasive species.

Keywords Alien species - Castor fiber - Castor canadensis $\cdot$ Habitat use $\cdot$ Monitoring counts $\cdot$ Citizen science

\section{Introduction}

Habitat requirements largely determine the distribution and abundance of species. Two very similar species, which share the same ecological niche, seldom coexist in the same area for a long time (Krebs 1972; Ehrlén and Morris 2015). A serious problem can develop when an alien species is introduced to an area where a very similar native species already exists (Ebenhard 1988). In the worst case, the invasive species may out-compete the native one. Invasive species may also transmit diseases or parasites to native ones (e.g. Kauhala 1996; Sainsbury et al. 2000), or they may alter the habitats of the native species (Rowe and Gill 1985). They can hybridize with native species (e.g. Ebenhard 1988; Genovesi et al. 2009), 
and invasive predators may have a detrimental effect on native prey animals (e.g. Ebenhard 1988; Kauhala 1996; Woods et al. 2003; Banks et al. 2008).

An invasive species potentially threatening a native species is the North American beaver (hereafter NA beaver, Castor canadensis), which is partly sympatric with the native Eurasian beaver (Castor fiber) in Finland (Kauhala and Turkia 2013; Kauhala and Karvinen 2018). The Eurasian beaver was hunted to extinction in Finland in 1868 (Granit 1900; Lahti 1972; Lahti and Helminen 1974) but was reintroduced in the 1930s when 17-19 individuals were brought from Norway (e.g. Lahti and Helminen 1969; Härkönen 1999). Seven NA beavers were also introduced (Lahti and Helminen 1969, 1980; Ermala et al. 1989), because at the time their status as a distinct species was not known. Both species were released into several areas in Finland, but the Eurasian beaver population survived (only one pair) and started to increase slowly only in Satakunta in southwestern Finland, a region where no NA beavers were introduced (Fig. 1). NA beavers flourished especially well in eastern Finland (Fig. 1; Ermala 1996). The range and population size of the NA beaver increased faster than that of the Eurasian beaver, reaching an estimated population size of $>10000$ in 2017 (Kauhala and Karvinen 2018). The present range of the NA beaver covers most of eastern and central Finland, and sporadically Lapland, whereas that of the Eurasian beaver is restricted to a smaller area in western Finland (mainly Satakunta), and its population size is estimated to be 3300-4500 (Fig. 1; Kauhala and Karvinen 2018).

The range of the NA beaver has spread westwards in recent decades and partly overlaps the distribution of the Eurasian beaver in three areas, i.e., in the regions of Pirkanmaa, Pohjanmaa and Lapland (Fig. 1; Kauhala and Turkia 2013; Kauhala and Karvinen 2018; Isotouru et al., unpubl. data). It is possible that the two species have lived close to each other for some decades in Pirkanmaa, and at present, they even live in the same river systems and have, at least on two occasions, been found near the same lodge (Kauhala and Karvinen 2018). Because the Eurasian beaver did not survive after the original introductions in areas where both beaver species were present, it is assumed that the spread of the NA beaver is a threat for the Eurasian beaver (Liukko et al. 2016). The Eurasian beaver is classified as 'near threatened' in Finland (Liukko et al. 2016). The NA beaver has larger litters, which may be the reason for a more rapid growth rate of the population and may give it the advantage when the species meet (Parker et al. 2012).

Both beaver species are monogamous and territorial (Wilsson 1971; Nolet and Rosell 1994), and the ecological niches of them are fairly similar. Both species feed mainly on deciduous trees (Collen and Gibson 2001; Danilov et al. 2011; Parker et al. 2017); and in summer, terrestrial and aquatic herbs are also part of their diet (Wilsson 1971; Lahti and Helminen 1974; Nolet and Rosell 1994; Danilov et al. 2011). A mature beaver couple builds a lodge, a bank burrow, or a combination of the two, with an underwater entrance (Wilsson 1971; Lahti and Helminen 1974; MüllerSchwartze 2011). The critical water depth needed for a lodge may be about $40 \mathrm{~cm}$ (Rosell and Parker 1996; Baskin 2011); that is, the lodges of the beavers are always by the water area. A beaver family can occupy several lodges during the summer, but only one lodge is used during the winter (Lahti and Helminen 1974). Beavers are central-place foragers (e.g. Haarberg and Rosell 2006), and they commonly forage within a 50-meter radius from the lodge, which can be defined as their core area. Beavers can, however, move up to $250 \mathrm{~m}$ from water in search of good foraging trees (Smith et al. 1994; Müller-Schwartze 2011). One family group needs approximately $1-2 \mathrm{~km}$ of suitable habitat along a watercourse or shoreline (defined as their territory, Hartman 1994). Beavers usually inhabit forested areas, but may also use agricultural areas, especially areas that are mosaics of fields and forest patches along a river system. The range of the Eurasian beaver in Finland covers especially large agricultural areas, and they can make dams and bank burrows in small ditches between two fields and even forage in fields (Kauhala and Karvinen 2018). We have also received observations of beavers in small towns or villages from the public, which indicates that they do not always avoid human presence.

We compared the habitat use of the two beaver species within their core areas around lodges and on a larger territory scale, and compared the habitat use with other habitats available in the landscape (Johnson 1980). We used citizen-science data on beaver lodge locations in the main distribution area of the species in Finland. We predicted, based on earlier studies (e.g. Lahti and Helminen 1974; Hartman 1994; Nelner and Hood 2011), that (1) the habitat use of the two beaver 
Fig. 1 Map of the current distribution of beaver observations in Finland and the successful introduction sites of the Eurasian and the North American beaver, from where the species began to spread (unsuccessful introduction sites are not included). The study area consisted of the distribution areas of beavers, except Lapland (gray area in the map). Eurasian beavers in Lapland have apparently dispersed to Finland from Sweden. The zoomed picture is from the area in Pirkanmaa, where the species are partly sympatric

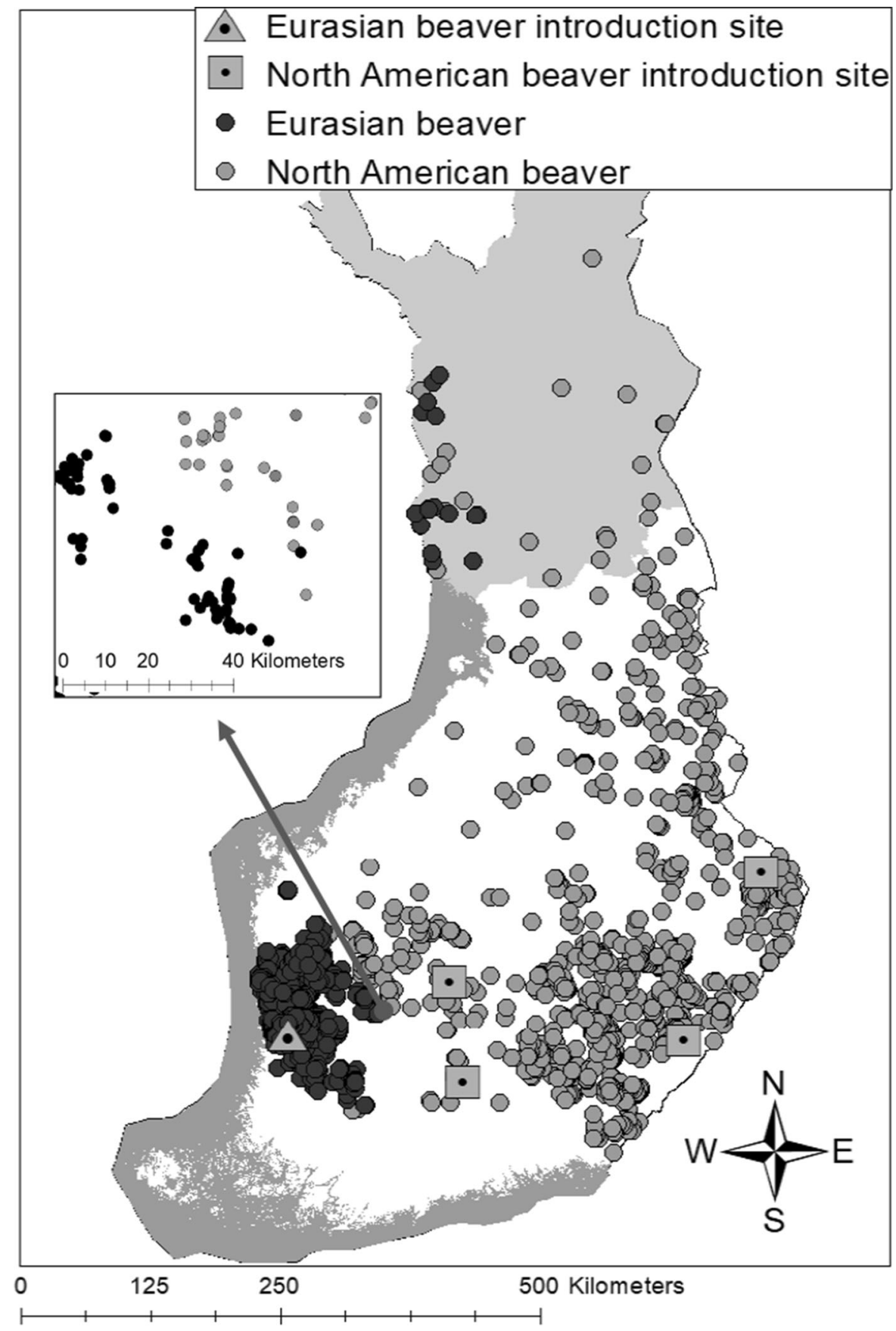

species would be fairly similar and they would favor habitat patches with deciduous forests. However, there still may be a difference between the species in the amount of birches and other deciduous trees near their lodges, for example, due to differences in the family structure between the species (Parker et al. 2012). We further predicted (2) that the two beaver species would be found to differ in their habitat use in relation to agricultural and urban areas, because the native beaver lives in an agriculture-dominated landscape, whereas the NA beaver lives in a forest-dominated area with a sparse human population. We discuss the possible role of habitat requirements in the conservation of the 
native Eurasian beaver and in controlling the invasive NA beaver in Finland.

\section{Methods}

Study area

The study area consisted of the distribution areas of beavers in Finland, with the exception of Lapland (Fig. 1). The landscape in Finland consists largely of coniferous and mixed forests with approximately 168 000 lakes with an area of at least $500 \mathrm{~m}^{2}$ (Statistics Finland 2018a) and approximately $20,000 \mathrm{~km}$ of rivers (Biodiversity 2018). Forests cover approximately $75 \%$ of the land area and the Scots pine $(50 \%$; Pinus sylvestris), the Norway spruce (30\%; Picea abies) and birches (17\%; Betula sp.) are the most common tree species (Luke 2018a). Ten percent of the land cover is composed of inland waters, $9 \%$ of agricultural areas and $3.5 \%$ of urban areas, i.e. population centers including residential, industrial and commercial areas (Biodiversity 2018). The human population density is higher where the main distribution of the Eurasian beaver is, in Satakunta in southwestern Finland, with 28.18 ind. $/ \mathrm{km}^{2}$, than the human population density of the area where the main distribution of the North American beaver is, in eastern Finland, with 3.66, 9.18, 10.32 and 14.71 ind./ $\mathrm{km}^{2}$ in Kainuu, North Karelia, Etelä-Savo and Pohjois-Savo, respectively (Statistics Finland 2018a). Agriculture is more dominant in Satakunta with $16.7 \%$ of the area being agricultural land in 2013, compared to eastern Finland with 1.4, 3.9, 3.8 and $7.2 \%$ being agricultural land in Kainuu, North Karelia, Etelä-Savo and Pohjois-Savo, respectively (Luke 2018b). Crop cultivation is more common in Satakunta compared to eastern Finland, where cattle farming is more common. Lakes are more abundant in eastern Finland (also called the Lake District) with inland waters covering a minimum of $12.1 \%$ of the area of Kainuu to a maximum of $25.5 \%$ of Etelä-Savo, when in Satakunta the proportion is $5.3 \%$ (Järviwiki 2018).

\section{Data for beavers}

Lodge sites were obtained from monitoring counts carried out by the Finnish Game and Fisheries
Research Institute (Natural Resources Institute Finland, Luke since 1.1.2015). Beaver lodge coordinates were collected by hunters during the fall of 2013 and 2014 and the spring of 2015 (Brommer et al. 2017; cases of a site having data for multiple years were omitted from the data). The environmental variables used in the study were the same for these years. Hunters usually know their hunting areas well, and this method should supply a comprehensive proportion of lodges, but obviously not all lodges could be detected with the citizen science approach. Only inhabited wintering lodges were reported to estimate the number of beaver family groups in each game management district. An occupied winter lodge can be recognized by a food cache near the lodge (Müller-Schwartze 2011). The beaver species could not be identified in the field by a citizen scientist collecting the lodgelocation data. Instead, the identification of beaver species was based on the historic distribution of beavers in Finland (Fig. 1), DNA analyses from wood chips collected near beaver lodges and skull morphometry from hunted beavers (Kauhala and Timonen 2016).

The coordinates of 758 and 628 Eurasian beaver and North American beaver lodges, respectively, were analyzed in GIS (ESRI ArcMap 10.2.2; ESRI 2011) with land cover variables. The geographic information of streams $<20 \mathrm{~m}$ (as polylines) and lakes and large rivers (as polygons) were added from the data of the National Land Survey of Finland (topographic map 1:100,000) (Maanmittauslaitos 2/2015), and lakes and large rivers were transformed to polylines (from now on, all are called watercourses). Wetlands were partly included in these data, as there are no large separate wetland areas in the Finnish landscape (except peatbogs). Only lodges that were within $50 \mathrm{~m}$ from a watercourse based on GIS were included to remove possible errors in coordinates and to remove cases where lodges were in small streams not digitized in GIS. This was necessary because the territory buffers were generated along watercourses (see below). Based on this, 328 lodges for the Eurasian beaver and 159 lodges for the North American beaver were excluded from the analysis. The Eurasian beaver lives in a more agriculture-dominated landscape with small ditches, which is probably why more of this species' lodges were in undigitized watercourses. We did not have a reason to suspect this removal of the lodges with uncertain locations would affect our 
analysis because the number of lodges for both species was still quite high, and the Eurasian beaver was not overrepresented in relation to the NA beaver. On the contrary, some quality checks for the lodge locations provided by the citizen scientists should be done. Only wintering lodges should have been reported, but lodges were sometimes very close to each other. Therefore, lodges that were closer than one $\mathrm{km}$ to another lodge along a watercourse were counted as the same family group's lodges (Hartman 1994), because family groups' home ranges do not usually overlap (Korbelová et al. 2016). Only the centermost lodge in a family group's area was included in the analysis. In the end, we used coordinates of 428 lodges of the Eurasian beaver and 466 lodges of the NA beaver that were suitable for generating the buffers.

Habitat variables in core areas, territories and available environment

The habitat variables used in the analyses were: the volume of birches, volume of other deciduous trees, distance from urban areas and distance from agricultural areas. The volumes of birches and other deciduous trees $\left(\mathrm{m}^{3} / \mathrm{ha}\right)$ were computed using the tree volume data from the forest inventory data of the Finnish Forest Research Institute in 2013 (Luke 2015). The data gives the volume of birches (Betula pendula, B. pubescens and B. nana) and other deciduous trees as one group, including the Eurasian aspen (Populus tremula), alder (Alnus incana and A. glutinosa), European mountain ash or rowan (Sorbus aucuparia) and the goat willow (Salix caprea) (Ylitalo 2013) within $16 \mathrm{~m} \times 16 \mathrm{~m}$ squares. The distances from the urban areas and agricultural areas were the nearest neighbor arithmetic distance from the lodge/random point. The agricultural area and urban area were added from the 2013 Corine land cover data for Finland with $20 \mathrm{~m} \times 20 \mathrm{~m}$ squares (SYKE $2 / 2015$ ). The agricultural area included classes 2111-2441 (arable land, pastures etc.). The urban area included classes 1111-1424 (urban fabric, industrial units, dump sites etc.) and 4122 (peat bogs in commercial use). Roads were not included as possible sources of disturbance, because roads located closest to lodges were mainly the smallest roads with very low traffic.

Habitat variables were measured in two scales: within a core area around lodges and within a territory. Core areas were calculated by buffering the lodges with a radius of $50 \mathrm{~m}$ (e.g. Müller-Schwartze 2011). We calculated the volumes of birches and other deciduous trees per hectare within the core area and the distances from the lodge to the nearest agricultural and urban areas. In the second scale, the territory extended a maximum of $500 \mathrm{~m}$ from the core area along all watercourses connected to the core area and $250 \mathrm{~m}$ from the shoreline of the lake or from the middle of the stream, i.e., the maximum foraging distance on land according to Müller-Schwartze (2011) (Fig. 2). With a maximum distance of $500 \mathrm{~m}$, each territory included shoreline (on both sides of the watercourse) with a mean length of $2050 \mathrm{~m}$ for the Eurasian beaver (range 484-5654 m) and $2438 \mathrm{~m}$ for the NA beaver (range 327-9746 m). We also calculated the volumes of birches and other deciduous trees per hectare within the territory. The nearest neighbor distances of the territory from the agricultural and urban areas were calculated using the average arithmetic distance of 100 random points placed within the territory (Fig. 2).

To compare habitat variables within core areas and territories with those available in the landscape in habitats close to riparian zone, we laid random points in the proximity of all watercourses in the landscape. We used random points that were a maximum of $250 \mathrm{~m}$ from a watercourse (from now on called a watercourse area) and did not overlap with a beaver territory. Random points were laid within each municipality in Finland with beaver lodge coordinates from the 2013 municipality division from the data of the National Land Survey (Maanmittauslaitos 2/ 2015). Municipalities were selected as the available landscape areas because the sizes of the municipalities are of suitable size for the beavers to potentially disperse (the median size of a municipality in Finland is $750 \mathrm{~km}^{2}$ ). The number of random points for each municipality was computed by multiplying the watercourse area as hectares (excluding beaver territories) in a municipality with the highest number of lodges (two species separately) per watercourse area found in all municipalities. The number of random points was then multiplied so that their total numbers were approximately tenfold compared to the number of lodges: 4452 for the Eurasian and 4874 for the NA beaver. We computed the volume of deciduous trees (birches and other deciduous trees separately) per hectare at each random point (intersecting with a $16 \mathrm{~m} \times 16 \mathrm{~m}$ square with tree volume), and the 
Fig. 2 A GIS image of the lodge site, the core area and the territory computed along the watercourses. Examples are from two Eurasian beaver lodges

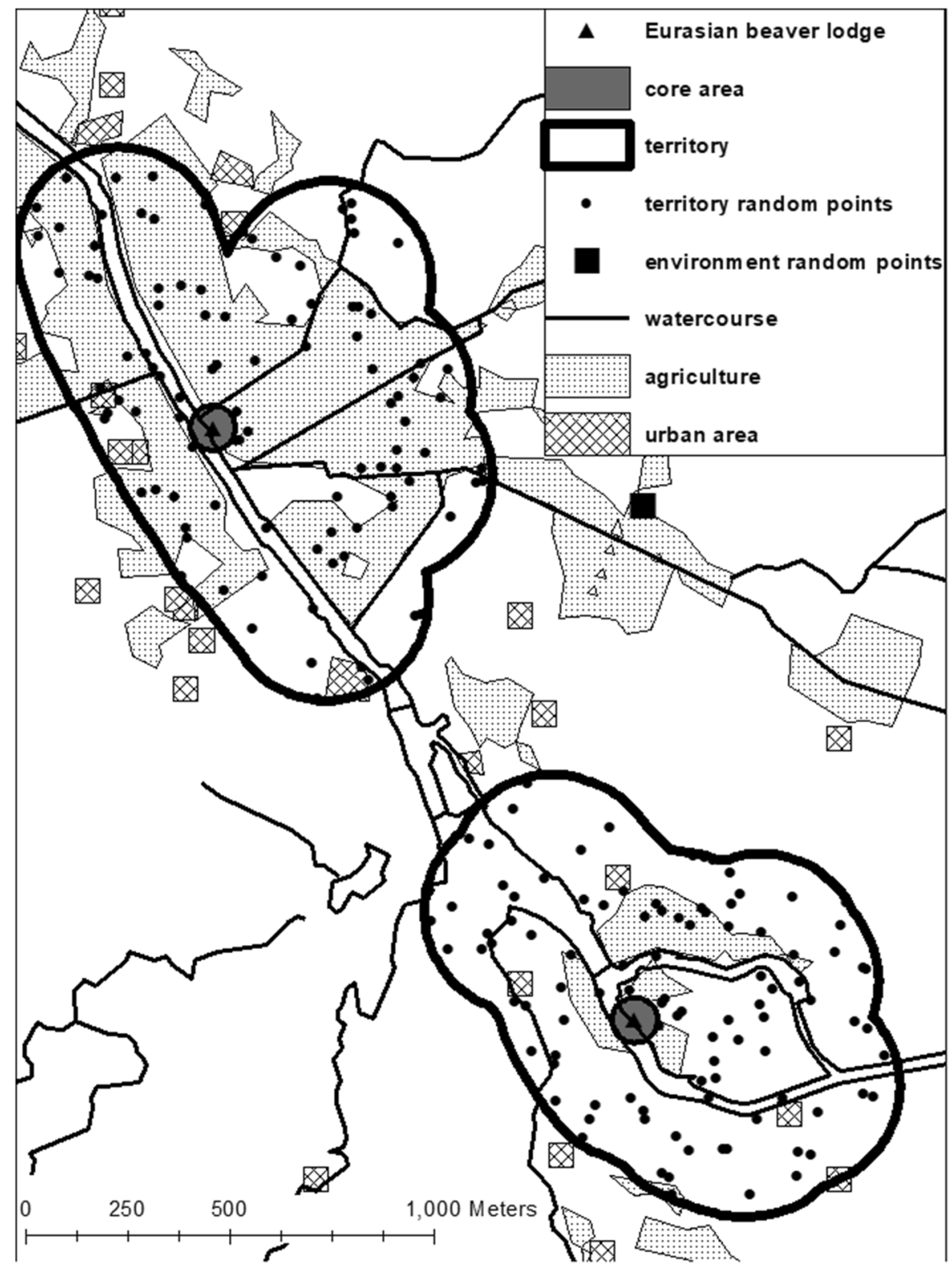

shortest arithmetic distances between random points and the nearest urban and agricultural areas.

Data from the sympatric Pirkanmaa area

A separate comparison was done for the beaver observations within the region where both species are sympatric (the region of Pirkanmaa; Fig. 1). A total of 50 coordinates, 25 for both species, were used for this analysis. Coordinates included beaver lodges (15 Eurasian (E); 7 NA), feeding sites (4 NA), sites where droppings were found (1 NA) and sites where beavers were shot (13 E; $10 \mathrm{NA}$; received from hunters who sent us beaver skulls for species determination, Kauhala and Timonen 2016) (from now on called activity sites. Volumes of birch and other deciduous trees within $250 \mathrm{~m}$ from each beaver activity site and distances to agricultural and urban areas from 100 random points in the $\mathrm{r}=250 \mathrm{~m}$ buffer were calculated. Only the 250-m buffer (territory scale) was selected for this analysis, because not all activity sites described the accurate location of the lodge. 
Statistical analysis

Analysis of the habitat use in core areas and territories of each beaver species

We compared the core areas and the territory buffers using conditional logistic regression analyses separately for the two beaver species (Duchesne et al. 2010). With conditional analyses, we could match the core areas and territories of each lodge for the analysis, that is, the response variable was the matched pair of used (core area) and available (territory). Explanatory variables were habitat characteristics, i.e., volumes of birches and other deciduous trees $\left(\mathrm{m}^{3} / \mathrm{ha}\right)$ and distances to agricultural and urban areas (more about conditional analysis, see e.g. Duchesne et al. 2010).

For a comparison of core area/territory versus random points in the landscape, we could not form matched pairs (conditional model). Instead, we built two logistic regression models, where the binomial response variable was the used habitat (1) of the core area or territory versus available habitat $(0)$ in the landscape, represented by random points along the shore of all watercourses in the municipality. Explanatory variables were habitat characteristics, i.e., volumes of birches and other deciduous trees $\left(\mathrm{m}^{3} / \mathrm{ha}\right)$ and distances to agricultural and urban areas. In addition, the municipality was included as a random variable in the model.

\section{Analysis for the differences in habitat use}

between the Eurasian beaver and the North American beaver

To analyze whether the habitat use differed between the species, we combined the data of both beavers and performed models similar to those described above (core vs. territory, core vs. landscape, territory vs. landscape). Conditional logistic regression was used when comparing the core area to territory, and binomial logistic regression when comparing the core area and territory to environment. In addition, we included the interaction terms between the class variable 'species' (1 Eurasian Beaver, 2 NA beaver) and the habitat variables in the models. The interaction terms were included separately for each habitat variable. Thus, we could test if habitat use differed between the Eurasian and the NA beaver. Because this analysis otherwise repeats the abovementioned analysis, we report only the observed significant results for interaction terms.

\section{Analysis for the habitat use in the region where species are sympatric}

For the comparison of habitat use of the invasive and native beavers in an area where they are sympatric (Pirkanmaa), we built a model were species (1 Eurasian beaver, 2 NA beaver) was the response variable. Explanatory variables were habitat characteristics, i.e. volumes of birches and other deciduous trees $\left(\mathrm{m}^{3} / \mathrm{ha}\right)$ and distances to agricultural and urban areas. In addition, type of observation was included as a class variable in the model (activity sites: 1 lodge, 2 other type of observations). In this analysis, we assumed that the availability of habitats was similar for NA beavers and Eurasian beavers, because they were living in the same area.

\section{Results}

Habitat use in core areas and territories

Core areas of both species included statistically significantly more birch than did territories in the model (Table 1). The volume of other deciduous trees was lower in the core areas than in the territories of the NA beaver (Table 1).

When comparing core areas and territories to random points available in the riparian landscape, the only statistically significant difference was that the Eurasian beaver's core areas and territories were closer to agricultural areas than random points were (Table 1). The core area and the territory of the NA beaver did not differ significantly from the landscape in any of the measured variables (Table 1).

Differences in habitat use between the Eurasian beaver and the North American beaver

The distance from agricultural areas, compared to the available environment (random points) differed between the native and invasive beaver (interaction term between beaver species and distance to agriculture; core: $\mathrm{F}_{1,10109}=4.88, \quad p=0.03$; territory: $\mathrm{F}_{1,10110}=4.04, p=0.04$; Table 2); that is, the mean distances to agricultural areas were greater in the NA 
Table 1 Test results of comparisons of the core area to the territory, the core area to the available riparian landscape (random points) and the territory to the landscape in the Eurasian $(n=428)$ and the North American beaver $(\mathrm{n}=466)$
Statistically significant results $(p \leq 0.05)$ are in bold

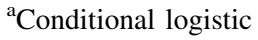
regression

${ }^{\mathrm{b}}$ Logistic regression

\begin{tabular}{|c|c|c|c|c|c|c|}
\hline Parameter & Estimate & SE & $\mathrm{DF}$ & \multicolumn{2}{|c|}{ Wald Chi square } & $\operatorname{Pr}>$ ChiSq \\
\hline \multicolumn{7}{|l|}{ Core area versus territory ${ }^{\mathrm{a}}$} \\
\hline \multicolumn{7}{|l|}{ Eurasian beaver } \\
\hline Birch & 0.2756 & 0.1008 & 1 & 7.48 & & 0.006 \\
\hline Other deciduous trees & 0.1018 & 0.0986 & 1 & 1.07 & & 0.30 \\
\hline Distance to agriculture & -0.3987 & 0.3446 & 1 & 1.34 & & 0.25 \\
\hline Distance to urban area & 0.2115 & 0.1734 & 1 & 1.49 & & 0.22 \\
\hline \multicolumn{7}{|l|}{ North American beaver } \\
\hline Birch & 0.2804 & 0.1204 & 1 & 5.42 & & 0.02 \\
\hline Other deciduous trees & -1.1301 & 0.2131 & 1 & 28.13 & & $<.0001$ \\
\hline Distance to agriculture & -0.2054 & 0.9896 & 1 & 0.04 & & 0.84 \\
\hline Distance to urban area & -0.1638 & 0.3212 & 1 & 0.26 & & 0.61 \\
\hline Parameter & Estimate & SE & & DF & $\mathrm{F}$ value & $\operatorname{Pr}>F$ \\
\hline \multicolumn{7}{|c|}{ Core area versus landscape } \\
\hline \multicolumn{7}{|l|}{ Eurasian beaver } \\
\hline Birch & 0.0529 & 0.0577 & & 4875 & 0.84 & 0.36 \\
\hline Other deciduous trees & 0.0199 & 0.0404 & & 4875 & 0.24 & 0.62 \\
\hline Distance to agriculture & -1.5328 & 0.0620 & & 4875 & 40.39 & $<.0001$ \\
\hline Distance to urban area & 0.1696 & 0.0906 & & 4875 & 3.51 & 0.06 \\
\hline \multicolumn{7}{|l|}{ North American beaver } \\
\hline Birch & 0.0359 & 0.0554 & & 5334 & 0.42 & 0.52 \\
\hline Other deciduous trees & -0.1471 & 0.0793 & & 5334 & 3.44 & 0.06 \\
\hline Distance to agriculture & -0.0619 & 0.0620 & & 5334 & 1.00 & 0.32 \\
\hline Distance to urban area & 0.0125 & 0.0647 & & 5334 & 0.04 & 0.85 \\
\hline Parameter & Estimate & SE & & $\mathrm{DF}$ & F value & $\operatorname{Pr}>F$ \\
\hline \multicolumn{7}{|l|}{ Territory versus landscape ${ }^{b}$} \\
\hline \multicolumn{7}{|l|}{ Eurasian beaver } \\
\hline Birch & -0.0532 & 0.0623 & & 4875 & 0.73 & 0.39 \\
\hline Other deciduous trees & 0.0268 & 0.0459 & & 4875 & 0.34 & 0.56 \\
\hline Distance to agriculture & -1.4119 & 0.2404 & & 4875 & 34.49 & $<.0001$ \\
\hline Distance to urban area & 0.1394 & 0.0927 & & 4875 & 2.26 & 0.13 \\
\hline \multicolumn{7}{|l|}{ North American beaver } \\
\hline Birch & 0.0349 & 0.0551 & & 5334 & 0.40 & 0.53 \\
\hline Other deciduous trees & -0.0321 & 0.0615 & & 5334 & 0.27 & 0.60 \\
\hline Distance to agriculture & -0.0576 & 0.0620 & & 5334 & 0.86 & 0.35 \\
\hline Distance to urban area & 0.0166 & 0.0659 & & 5334 & 0.06 & 0.80 \\
\hline
\end{tabular}

Habitat use of beavers in the region where species are sympatric

In comparison of 50 beaver activity sites in the sympatric area (Pirkanmaa), there was more birch and less other deciduous trees near Eurasian beaver activity sites (habitats measured in a $250 \mathrm{~m}$ radius around the site, Table 3 ). Eurasian beaver activity 
Table 2 Raw data for habitat variables in core areas, territories and in the landscape (environment available in the study area) for the Eurasian and the North American beavers. To highlight the comparison between the core area versus territory versus study area, the mean ( $\pm \mathrm{sd})$ for the smaller scale is represented first and the mean for the larger scale is on the second row, and the difference between the two means is in brackets.
Statistically significant differences between the species are in bold font (the analysis with the combined data of both beavers with interaction term "species" to study differences between species, see the main text). $n=428$ and $n=466$ lodges, and random points in available study area $n=4452$ and $n=4874$, for the Eurasian beaver and the North American beaver, respectively

\begin{tabular}{|c|c|c|c|}
\hline Habitat variable & $\begin{array}{l}\text { Core area versus } \\
\text { territory (difference) }\end{array}$ & $\begin{array}{l}\text { Core area versus } \\
\text { environment (difference) }\end{array}$ & $\begin{array}{l}\text { Territory versus } \\
\text { environment(difference) }\end{array}$ \\
\hline \multirow[t]{2}{*}{$\operatorname{Birch}\left(\mathrm{m}^{3} / \mathrm{ha}\right)$} & $691 \pm 569$ & $691 \pm 569$ & $586 \pm 285$ \\
\hline & $586 \pm 285$ & $589 \pm 866$ & $589 \pm 866$ \\
\hline \multirow[t]{3}{*}{ Eurasian } & (104) & $(102)$ & $(-3)$ \\
\hline & $653 \pm 484$ & $653 \pm 483$ & $684 \pm 231$ \\
\hline & $684 \pm 231$ & $594 \pm 799$ & $594 \pm 799$ \\
\hline North American & $(-31)$ & $(59)$ & $(90)$ \\
\hline \multirow[t]{2}{*}{ Other deciduous trees $\left(\mathrm{m}^{3} / \mathrm{ha}\right)$} & $212 \pm 328$ & $212 \pm 328$ & $167 \pm 130$ \\
\hline & $167 \pm 130$ & $134 \pm 508$ & $134 \pm 508$ \\
\hline \multirow[t]{3}{*}{ Eurasian } & $(45)$ & $(77)$ & $(32)$ \\
\hline & $126 \pm 122$ & $126 \pm 122$ & $156 \pm 81$ \\
\hline & $156 \pm 81$ & $120 \pm 337$ & $120 \pm 337$ \\
\hline North American & $(-31)$ & (6) & $(36)$ \\
\hline \multirow[t]{2}{*}{ Distance to agriculture (m) } & $304 \pm 480$ & $304 \pm 480$ & $314 \pm 438$ \\
\hline & $314 \pm 438$ & $495 \pm 615$ & $495 \pm 615$ \\
\hline \multirow[t]{3}{*}{ Eurasian } & $(-10)$ & $(-191)$ & $(-181)$ \\
\hline & $1221 \pm 1300$ & $1221 \pm 1301$ & $1221 \pm 282$ \\
\hline & $1221 \pm 1282$ & $1621 \pm 2101$ & $1621 \pm 2101$ \\
\hline North American & $(0)$ & $(-400)$ & $(-401)$ \\
\hline \multirow[t]{2}{*}{ Distance to urban area $(\mathrm{m})$} & $400 \pm 405$ & $400 \pm 405$ & $393 \pm 365$ \\
\hline & $393 \pm 365$ & $442 \pm 413$ & $442 \pm 413$ \\
\hline \multirow[t]{3}{*}{ Eurasian } & (7) & $(-41)$ & $(-48)$ \\
\hline & $489 \pm 450$ & $489 \pm 450$ & $489 \pm 403$ \\
\hline & $489 \pm 403$ & $639 \pm 647$ & $639 \pm 647$ \\
\hline North American & $(0)$ & $(-149)$ & $(-150)$ \\
\hline
\end{tabular}

sites were also closer to agricultural areas than NA beaver sites in Pirkanmaa (Table 3).

\section{Discussion}

An important difference between the native Eurasian beaver and the invasive NA beaver was related to their distance from agricultural areas, as predicted. For the NA beaver, the average distance to the nearest agricultural area was more than $1200 \mathrm{~m}$ from lodges, whereas it was approximately $300 \mathrm{~m}$ for the Eurasian beaver in the whole data. Agriculture is more dominant in the range of the Eurasian beaver, but still they were located closer to agricultural areas than random points in the landscape. In the main distribution area of the Eurasian beaver in Finland, we even have observations of some beavers living in small ditches between agricultural fields (Kauhala and Karvinen 2018). Additional forage might attract them close to agriculture because they might also forage in fields (Danilov et al. 2011). The proportion of agricultural land is smaller in the range of the NA beaver than that of Eurasian beaver, which may be one reason why the former utilizes these areas less. Thus, the features in the current environments may partly explain the difference in utilizing agricultural areas. However, there may also be differences in species-specific 
behavior and, interestingly, the NA beaver was also further from agriculture in the sympatric area. This indicates that at the moment the NA beaver does not utilize agricultural areas similarly to the Eurasian beaver. Nelner and Hood (2011) report that NA beavers can utilize agricultural wetlands, whereas Dieter and McCabe (1989) suggest that they avoid grazed areas as lodge sites because of a lack of food and building material. The invasion of the NA beaver into the current range of the native Eurasian beaver in Finland may thus depend, at least partly, on the ability of the species to adapt to agriculture-dominated areas.

Contrary to our prediction, neither species avoided urban areas, but neither did they favor them. It might be that the urban area close to beavers in Finland consists mostly of recreational cottages that the beavers do not find disturbing or attracting. Earlier studies indicate that even highly used built up areas are not necessarily unfavorable to beavers, as they are known to adapt to the vicinity of humans (Korbelová et al. 2016), even in highly urbanized regions (Dewas et al. 2012). We used citizen science data in our study, which does not include all locations of lodges in the study area. Lodges close to urban areas may be underrepresented in our data because the data were collected by hunters during moose hunting, which does not usually take place in the proximity of human settlements. On the other hand, lodges close to human settlements are easy to observe.

Both species appeared quite flexible in their habitat use, as the habitats at the core areas and territories, apart from the effect of agricultural areas, did not differ much from those available in the landscape. Thus, the habitat selection of beavers is more likely determined by factors related to water bodies (Hartman 1994) than only to environmental variables measured in the current study. For instance, narrow rivers that are 1.5-3 m deep with low flow and low shores are considered better for beavers than broader rivers with rapid flow or lakes with steep slopes (Danilov et al. 2011).

However, both species had statistically significantly more birch in the core areas than in the territories. The difference between core areas and territories was greater in the Eurasian beaver than in the NA beaver. Furthermore, in Pirkanmaa, more birch and fewer other deciduous trees were located at the activity sites of the Eurasian beaver than at those of the NA beaver. Unfortunately, we could not separate aspen (Populus tremula), an important forage tree for beavers, from other deciduous trees. Also, separate data of willow (Salix spp.) which are often selected by beavers (Gerwing et al. 2013), was not available. According to Kauhala and Karvinen (2018), signs of consumed aspen, willows and alder (Alnus spp.) were often found in the core areas of both beaver species, and the Eurasian beaver seemed to use willows and alders more often than the NA beaver. The restrictions of our data may thus partly explain the lack of some expected effects of the group 'other deciduous trees' in our analysis. However, birch is the most abundant deciduous tree in Finland and its abundance might better indicate the presence of deciduous forest habitat near beaver lodges than the abundance of other deciduous trees that are scarce in Finland. The difference in the amount of birch between the beaver species was, however, quite small measured in $\mathrm{m}^{3}$ of trees (Table 2). Thus, it remains unclear how applicable this difference could be in habitat management aiming to control the spread of the invasive NA beavers to the area of the native Eurasian beaver.

Table 3 Test results of comparison of the Eurasian beaver's $(n=25)$ and the North American beaver's $(n=25)$ activity sites $(\mathrm{r}=250 \mathrm{~m})$ in the sympatric Pirkanmaa area. The probability that species is the Eurasian beaver is modeled

\begin{tabular}{|c|c|c|c|c|c|c|}
\hline Parameter & & Estimate & SE & $\mathrm{DF}$ & F value & $\operatorname{Pr}>\mathrm{F}$ \\
\hline Birch & & 1.5129 & 0.6905 & 44 & 4.80 & $\mathbf{0 . 0 3}$ \\
\hline Other deciduous trees & & -1.7222 & 0.6815 & 44 & 6.39 & 0.02 \\
\hline Distance to agriculture & & -1.4517 & 0.7234 & 44 & 4.03 & 0.05 \\
\hline Distance to urban area & & -0.2790 & 0.6402 & 44 & 0.19 & 0.67 \\
\hline \multirow[t]{2}{*}{ Observation type } & Other & -1.3766 & 0.7508 & 44 & 3.36 & 0.07 \\
\hline & Lodge & 0 & & & & \\
\hline
\end{tabular}

Statistically significant results $(p \leq 0.05)$ are in bold 
In the present study, the diameter of the core area was $50 \mathrm{~m}$ from the lodge, whereas that of the territory was $250 \mathrm{~m}$ from the shoreline. Therefore, the result of more birch in the core area than in the territory could have arisen from the fact that beavers choose a lodge site where deciduous trees are abundant along the shoreline. Central-place foragers, such as beavers, prefer to forage close to the shoreline and forage more selectively (especially aspen) when going further into dry land according to the optimal foraging theory (e.g. Haarberg and Rosell 2006; Baskin 2011; Gerwing et al. 2013; Salandre et al. 2017). Beavers are probably reluctant to move far from water, especially in areas where predation risk is high (Smith et al. 1994; Baskin 2011). According to Basey and Jenkins (1995), foraging beavers take into account both the energy obtained and the risk of predation. It is also possible that Eurasian beavers need a smaller area for foraging than NA beavers, due to their smaller family groups (Parker et al. 2012). Graf et al. (2016) report that the Eurasian beaver in Norway makes a trade-off between the costs of patrolling larger territories against the benefits of foraging closer to the shoreline, which in this case would mean foraging in the core area. The density of Eurasian beaver lodges was also much higher than that of NA beaver lodges in our data (Kauhala 2018), which suggests smaller territories for the Eurasian beaver because territory size and population density are often negatively correlated (e.g. Morse 1976). In another study (Kauhala and Karvinen 2018), the mean size of core areas of the Eurasian beaver indeed seemed to be smaller than that of the NA beaver (6.4 ha vs. 10.9 ha), but the difference was not significant.

We conclude that the most apparent difference in habitat use between the NA and Eurasian beavers that may affect the invasion speed of the former was related to the distance from agricultural areas. The native Eurasian beaver lives near agricultural areas in Finland, and if the NA beaver avoids settling close to agriculture, it may not invade deeper into the Eurasian beaver's current range. Thus, management favoring birch forest patches within agricultural areas might benefit Eurasian beavers over the invasive NA beavers. Otherwise, the observed differences in the amount of birch near lodges seemed minor, and both beaver species appear quite flexible in their habitat use. Thus, interspecific competition for the best habitat patches likely occurs. These patches would probably be productive mixed forest patches, because pure deciduous forests are not common in Finland.

Biological invasions are predicted to increase in the future, for example, due to climate change and habitat fragmentation (Hulme et al. 2009). One possible way to manage invasive species could be management of habitats to favor the native species (e.g. Lurz et al. 1998; Wauters and Gurnell 1999). In our case, it remains questionable how effective this approach would be, and other methods may be more effective in control of the invasive species. Preventing dispersal of the invasive species, for example, by using an earlywarning system to identify and locate the individuals of the invasive species and removing them in and close to the areas of contact, might be helpful (Genovesi 2005).

Acknowledgements Open access funding provided by University of Turku (UTU) including Turku University Central Hospital. We wish to thank all the volunteers who have participated in counting beaver lodges over the years. R. Koivunen helped us to manually save the coordinates. We are also grateful to Leigh Ann Lindholm for proofreading the manuscript, and to the reviewers for their comments that improved the manuscript greatly. This study was supported by the Maj and Tor Nessling Foundation (to RA).

Open Access This article is distributed under the terms of the Creative Commons Attribution 4.0 International License (http:// creativecommons.org/licenses/by/4.0/), which permits unrestricted use, distribution, and reproduction in any medium, provided you give appropriate credit to the original author(s) and the source, provide a link to the Creative Commons license, and indicate if changes were made.

\section{References}

Banks PB, Nordström M, Ahola M, Salo P, Fey K, Korpimäki E (2008) Impacts of alien mink predation on island vertebrate communities of the Baltic Sea Archipelago: review of a long-term experimental study. Boreal Environ Res Suppl 13(A):3-16

Basey JM, Jenkins SH (1995) Influences of predation risk and energy maximization of food selection by beavers (Castor canadensis). Can J Zool 73:2197-2208

Baskin LM (2011) Predators as determinants of beaver alertness and shelter-making behaviour. In: Sjöberg G, Ball JP (eds) Restoring the Eurasian beaver: 50 years of experience. Pensoft Publishers, Sofia, pp 271-280

Biodiversity (2018) https://www.biodiversity.fi/en/biodiversity. Accessed 23 Oct 2018

Brommer JE, Alakoski R, Selonen V, Kauhala K (2017) Population dynamics of two beaver species in Finland inferred from citizen-science census data. Ecosphere 8:e01947 
Collen P, Gibson RJ (2001) The general ecology of beavers (Castor spp.), as related to their influence on stream ecosystems and riparian habitats, and the subsequent effects on fish-a review. Rev Fish Biol Fish 10:439-461

Danilov P, Kanshiev V, Fyodorov F (2011) Characteristics of North American and Eurasian beaver ecology in Karelia. In: Sjöberg G, Ball JP (eds) Restoring the European Beaver: 50 years of experience. Pensoft Publishers, Sofia, pp 55-72

Dewas M, Herr J, Schley L, Angst C, Manet B, Landry P, Catusse M (2012) Recovery and status of native and introduced beavers Castor fiber and Castor canadensis in France and neighboring countries. Mammal Rev 42:144-165

Dieter CD, McCabe TR (1989) Factors influencing beaver lodge-site selection on a prairie river. Am Midl Nat 122:408-411

Duchesne T, Fortin D, Courbin N (2010) Mixed conditional logistic regression for habitat selection studies. J Anim Ecol 79:548-555

Ebenhard T (1988) Introduced birds and mammals and their ecological effects. Swed Wildl Res (Viltrevy) 13:1-107

Ehrlén J, Morris WF (2015) Predicting changes in the distribution and abundance of species under environmental change. Ecol Lett 18:303-314

Ermala A (1996) Euroopanmajava, kanadanmajava. In: Lindén H, Hario M, Wikman M (eds) Riistan jäljille. Riista- ja kalatalouden tutkimuslaitos and Edita, Helsinki, pp 30-33

Ermala A, Helminen M, Lahti S (1989) Some aspects of the occurrence, abundance and future of the Finnish beaver population. Suomen Riista 35:108-118 (in Finnish with English summary)

ESRI (2011) ArcGIS desktop. Release 10. Environmental Systems Research Institute, Redlands, California, USA

Genovesi P (2005) Eradications of invasive alien species in Europe: a review. Biol Invasions 7:127-133

Genovesi P, Bacher S, Kobelt M, Pascal M, Scalera R (2009) Alien mammals of Europe. In: Drake JA (ed) Handbook of alien species in Europe, vol 3. Invading nature: Springer series in invasion ecology. Springer, Berlin, pp 119-128

Gerwing TG, Johnson CJ, Alström-Rapaport C (2013) Factors influencing forage selection by the North American beaver (Castor canadensis). Mammal Biol 78:79-86

Graf PM, Mayer M, Zedrosser A, Hackländer K, Rosell F (2016) Territory size and age explain movement patterns in the Eurasian beaver. Mammal Biol 81:587-594

Granit AW (1900) Bävern i Finland. Tidskrift för Jägare och Fiskare 8:45-55

Haarberg O, Rosell F (2006) Selective foraging on woody plant species by the Eurasian beaver (Castor fiber) in Telemark, Norway. J Zool 270:201-208

Härkönen S (1999) Forest damage caused by the Canadian beaver (Castor canadensis) in South Savo, Finland. Silva Fennica 33:247-259

Hartman G (1994) Ecological studies of a reintroduced beaver (Castor fiber) population. SLU/Repro Uppsala

Hulme PE, Roy D, Cunha T, Larsson TB (2009) A pan-European inventory of alien species: rationale, implementation and implications for managing biological invasions. In: Drake JA (ed) Handbook of alien species in Europe, vol 3.
Invading nature: Springer series in invasion ecology. Springer, Berlin, pp 1-14

Johnson D (1980) The comparison of usage and availability measurements for evaluating resource preference. Ecology 61:65-71

Kauhala K (1996) Introduced carnivores in Europe with special reference to central and northern Europe. Wildl Biol 2:197-204

Kauhala K (2018) Majavien pesälaskenta 2017 - Oma Riista lisäsi ilmoitusaktiivisuutta. Metsästäjä 3(2018):50-51

Kauhala K, Karvinen J (2018) Habitat use of beavers based on mapping in the field and lodge coordinates from hunters. Suomen Riista 64:21-34 (In Finnish with English summary)

Kauhala K, Timonen P (2016) What do beaver skulls reveal? Suomen Riista 62:7-18 (In Finnish with English summary)

Kauhala K, Turkia T (2013) Habitat use of beavers: preliminary comparison between a native and alien species). Suomen Riista 59:20-33 (In Finnish with English summary)

Korbelová J, Hamšíková L, Maloň J, Válková L, Vorel A (2016) Seasonal variation in the home range size of the Eurasian beaver: do patterns vary across habitats? Mammal Res 61:243-253

Krebs CJ (1972) Ecology: the experimental analysis of distribution and abundance. Harper and Row, New York

Lahti S (1972) Majavat. Suomen Nisäkkäät I. Otava, Keuruu, pp 285-308

Lahti S, Helminen M (1969) History of reintroductions and present population status of the beaver in Finland. Suomen Riista 21:67-75 (In Finnish with English summary)

Lahti S, Helminen M (1974) The beaver Castor fiber (L.) and Castor canadensis (Kuhl) in Finland. Acta Theriol 13:177-189

Lahti S, Helminen M (1980) Suomen majavien levinneisyyden muutokset vuosina 1965-1975 (Summary: The status of European and Canadian beavers in Finland in 1965-75). Suomen Riista 27:70-77

Liukko U-M, Henttonen H, Hanski IK, Kauhala K, Kojola I, Kyheröinen E-M, Pitkänen J (2016) The 2015 red list of finnish mammal species. Ympäristöministeriö and Suomen ympäristökeskus, $34 \mathrm{p}$

Luke (2015) http://kartta.luke.fi/

Luke (2018a) https://www.luke.fi/wp-content/uploads/2017/06/ finlands-forests-facts-2017-www.pdf. Accessed 23 Oct 2018

Luke (2018b) Statistics database. http://statdb.luke.fi/PXWeb/ pxweb/en/LUKE/?rxid=087d0937-e487-488a-b0fa-f9839 d9e6f4c. Accessed 26 Oct 2018

Lurz PWW, Garson PJ, Ogilvie JF (1998) Conifer species mixtures, cone crops and red squirrel conservation. Forestry 71:67-71

Maanmittauslaitos (2/2015). https://tiedostopalvelu.maanmit tauslaitos.fi/tp/kartta

Morse DH (1976) Variables affecting the density and territory size of breeding spruce-woods warblers. Ecology 57:290-301

Müller-Schwartze D (2011) The beaver. Its life and impact. Cornell University Press, Its life and impact

Nelner TB, Hood GA (2011) Effect of agriculture and presence of American beaver Castor canadensis on winter 
biodiversity of mammals. Wildl Biol 17:326-336. https:// doi.org/10.2981/09-097

Nolet BA, Rosell F (1994) Territoriality and time budgets in beavers during sequential settlement. Can J Zool 72:1227-1237

Parker H, Nummi P, Hartman G, Rosell F (2012) Invasive North American beaver Castor canadensis in Eurasia: a review of potential consequences and a strategy for eradication. Wildl Biol 18:354-365

Parker H, Zedrosser A, Rosell F (2017) Age-specific reproduction in relation to body size and condition in female Eurasian beavers. J Zool 302:236-243

Rosell F, Parker H (1996) The beaver's (Castor spp.) role in forest ecology: a key species returns (in Norwegian with English summary). Fauna 49:192-211

Rowe JJ, Gill MA (1985) The susceptibility of tree species to bark-stripping damage by grey squirrels (Sciurus carolinensis) in England and Wales. Q J For 79:183-190

Sainsbury AW, Nettleton P, Gilray J, Gurnell J (2000) Grey squirrels have high seroprevalence to a parapoxvirus associated with deaths in red squirrels. Anim Conserv 3:229-233

Salandre J, Beil R, Loehr JA, Sundell J (2017) Foraging decisions of North American beaver (Castor canadensis) are shaped by energy constraints and predation risk. Mammal Res 3:229-239

Smith DW, Trauba DR, Anderson RK, Peterson RO (1994) Black bear predation on beavers on an island in Lake Superior. Am Midl Nat 132:248-255
Statistics Finland (2018a) https://www.tilastokeskus.fi/tup/ suoluk/suoluk_alue_en.html. Accessed 30 Oct 2018

Statistics Finland (2018b) http://pxnet2.stat.fi/PXWeb/pxweb/ en/StatFin/StatFin_vrm_vaerak/?rxid=ea386a75-1a074df4-8111-82283c72dba7. Accessed 30 Oct 2018

SYKE (2/2015) National datasets (25 m, 1 ha) SYKE (partly METLA, MMM, MML, VRK). http://www.syke.fi/ avointieto

Wauters L, Gurnell J (1999) The mechanism of replacement of red squirrels by grey squirrels: a test of interference competition hypothesis. Ethology 105:1053-1071

Wilsson L (1971) Observations and experiments on the ethology of the European beaver (Castor fiber L.). Viltrevy 8:115-306

Woods M, Mcdonald RA, Harris S (2003) Predation of wildlife by domestic cats Felis catus in Great Britain. Mammal Rev 3:174-188

Ylitalo E (ed) (2013) Finnish statistical yearbook of forestry 2013. Finnish Forest Research Institute, Sastamala, Finland

Publisher's Note Springer Nature remains neutral with regard to jurisdictional claims in published maps and institutional affiliations. 